\title{
The Relation between Lipid Profile and Glycemic Control in Type 2 Diabetes Mellitus Patients in North Sumatera, Indonesia
}

\author{
Rusdiana Rusdiana $^{1 *}$, Sry Suryani Widjaja ${ }^{1}$, Maya Savira ${ }^{2}$ \\ ${ }^{1}$ Department of Biochemistry, Faculty of Medical, Universitas Sumatera Utara, Jl. dr. Mansur Kampus USU Medan 20155, \\ Indonesia; ' Department of Fisiology, Faculty of Medical, Universitas Sumatera Utara, Jl. dr. Mansur Kampus USU Medan \\ 20155, Indonesia
}

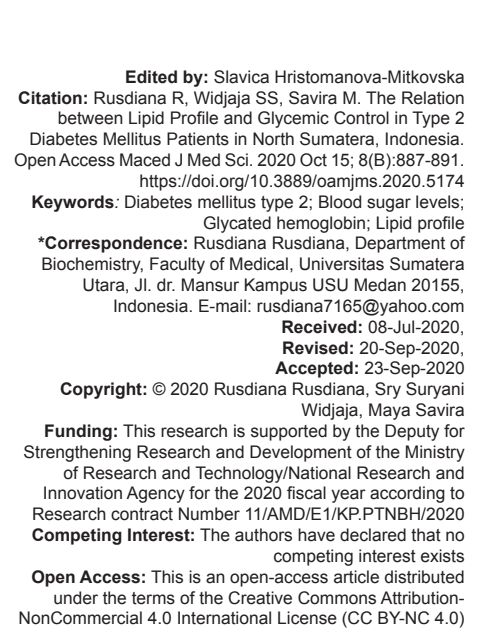

Introduction

Diabetes mellitus (DM) is a common metabolic disorder characterized by absolute or relative deficiencies in insulin secretion and/or insulin action associated with chronic hyperglycemia [1]. The prevalence is rapidly increasing in both developing and developed countries [2], [3]. Based on the International Diabetes Federation, in 2019, the prevalence of adult population aged 20-79 years who suffer from DM reaches 463 million and is expected to increase to 700 million by 2045 . It is stated that 1 in 5 people aged over 65 years suffer from DM and causes 4.2 million deaths globally [4]. Type 2 DM is often associated with an increased risk marker for cardiovascular disease. Individuals with Type 2 DM carry an absolute risk of major coronary events similar to that of non-diabetic individual with established coronary heart disease (CHD) because it is often associated with lipoprotein metabolism abnormalities that are responsible for microvascular or macrovascular complication risk [4], [5]. Furthermore, CHD has a higher mortality risk in people with DM than those who do not suffer from DM [6], [7].

In type 2 DM, lipid abnormalities are common. Typical findings include elevation of total and very low-density lipoprotein (LDL) cholesterol, triglyceride (TG) concentration, exaggerated postprandial lipemia, lower high-density lipoprotein (HDL) cholesterol, and a predominance of small, dense LDL-cholesterol (LDL-C) particles [8]. Insulin resistance often occurs in this process [9]. Increasing TGs have been associated with increased risk of CHD both in non-diabetic and diabetic subjects [10]. Dyslipidemia is related to lifestyle factors, such as diet and daily activities, and related to metabolic syndrome as well [11]. The pro-atherogenic properties of small LDL particles might be related to their ability to penetrate the arterial wall and thereby making them more susceptible to oxidation, indirectly linked with coronary artery disease [12].

This study aims to evaluate the relation of lipid profile with glycemic control in type $2 \mathrm{DM}$ who attended health-care centers in and around Medan city. 


\section{Materials and Methods}

In this study, there were 118 samples with type $2 \mathrm{DM}$, the samples were recruited from healthcare center in Medan, Binjai, and Stabat city, North Sumatera, Indonesia. The recruitment was conducted from May to July 2020. Patients with diabetics who take oral hypoglycemic agents, follow specific diet regimen or incorporate insulin for glycemic control were included in the study. Permission from the Institutional Review Committee was obtained. Patients were informed with the detail of the study. Written consent was obtained from the patients before they participated in the study. Due to COVID-19, personal protective equipment was used to prevent COVID-19 transmission. In addition, all the samples wore mask whenever they were in the clinic.

We measured height and weight with the subjects standing in light clutches. Body mass index (BMI) was calculated by dividing the subject's weight in kilogram to the square of the subject's height in meters $\left(\mathrm{kg} / \mathrm{m}^{2}\right)$. Average blood pressure was calculated by measuring the subjects twice after the subject had been seated for at least $5 \mathrm{~min}$. The subject fasted overnight to provide a blood specimen. Blood samples were collected (using syringe) and transferred to Paramitha clinical laboratory immediately to be examined for blood sugar, glycosylated hemoglobin, and lipid profile. The examination of blood sugar levels (BSL) was conducted with hexokinase methods. Whereas, the examination of glycosylated hemoglobin was conducted with HPLC methods and the examination of lipid profile was conducted with direct CHOD PAP and GPO PAP. Glycosylated hemoglobin test was carried out for the patients because this examination is a gold standard for type 2 DM patients.

\section{Statistical analysis}

SPSS version 24.0 (SPSS Inc., Chicago, Illinois) statistical software was used for statistical analysis. All the variables in this sample of the study were tested by Shapiro-Wilk, the normal distribution variables $(p>0.005)$ were tested by parametric correlation test, but the abnormal distribution variables $(p<0.005)$ were tested by non-parametric test.

\section{Results}

We evaluated clinical and laboratory findings in 118 patients with Type $2 \mathrm{DM}$. Of the total number of subjects, $28.8 \%$ (34) were male, and $71.2 \%$ (84) of the subjects were female. There were 51 samples $(43.2 \%)$ with controlled type $2 \mathrm{DM}$ and 67 samples (56.8 \%) with uncontrolled type $2 \mathrm{DM}$. The lowest BMI of the samples was $17.63 \mathrm{~kg} / \mathrm{m}^{2}$ and the highest BMI was $46.44 \mathrm{~kg} / \mathrm{m}^{2}$, with average BMI of $26.17 \mathrm{~kg} / \mathrm{m}^{2}$ and $\mathrm{SD} 5.47 \mathrm{~kg} / \mathrm{m}^{2}$.

Table 1: Descriptive statistics

\begin{tabular}{llllll}
\hline Variables & $\mathrm{n}$ & Minimum & Maximum & Mean & $\mathrm{SD}$ \\
\hline HbA1c & 118 & 4.70 & 14.70 & 8.87 & 2.58 \\
BMl $\left(\mathrm{kg} / \mathrm{m}^{2}\right)$ & 118 & 17.63 & 46.44 & 26.17 & 5.47 \\
Abdominal circumference $(\mathrm{cm})$ & 118 & 64 & 121 & 90.80 & 10.93 \\
Systole $(\mathrm{mmHg})$ & 118 & 98 & 216 & 145.79 & 22.76 \\
Diastole $(\mathrm{mmHg})$ & 118 & 60 & 113 & 86.36 & 10.29 \\
BSL $(\mathrm{mg} / \mathrm{dL})$ & 118 & 73 & 610 & 254.55 & 135.01 \\
Cholesterol $(\mathrm{mg} / \mathrm{dL})$ & 118 & 111 & 342 & 216.53 & 44.65 \\
HDL $(\mathrm{mg} / \mathrm{dL})$ & 118 & 24 & 77 & 47.25 & 11.52 \\
LDL $(\mathrm{mg} / \mathrm{dL})$ & 118 & 50 & 259 & 127.47 & 37.42 \\
TG $(\mathrm{mg} / \mathrm{dL})$ & 118 & 49 & 1157 & 233.63 & 144.97 \\
\hline HbA1c: Glycated hemoglobin, BMl: Body mass index, BSL: Blood sugar level, HDL: High-density
\end{tabular}

lipoprotein, LDL: Low-density lipoprotein, TG: Triglyceride.

The lowest abdominal circumference was $64 \mathrm{~cm}$, the highest was $121 \mathrm{~cm}$ with $90.80 \mathrm{~cm}$ in average and SD of $10.93 \mathrm{~cm}$. The lowest glycated hemoglobin (HbA1c) value was $4.7 \%$ and the highest value was $14.7 \%$ with an average of $8.87 \%$ and SD value of $2.58 \%$. The minimum age of the samples was 35 years old; the maximum age was 79 years old with 56.96 years in average and SD of 9.43 years. The lowest measurement of blood pressure level was $98 \mathrm{mmHg}$ (systole) and $60 \mathrm{mmHg}$ (diastole); the highest measurement was $216 \mathrm{mmHg}$ and $113 \mathrm{mmHg}$ with average value of $145.79 \mathrm{mmHg}$ and $86.36 \mathrm{mmHg}$ and SD of 22.76 and $10.29 \mathrm{mmHg}$. The lowest BSL of the sample was $73 \mathrm{mg} / \mathrm{dL}$, the highest of BSL levels was $610 \mathrm{mg} / \mathrm{dL}$, and the average BSL was $254.55 \mathrm{mg} / \mathrm{dL}$ and SD 135.01 $\mathrm{mg} / \mathrm{dL}$. The lowest cholesterol value of the sample was $111 \mathrm{mg} / \mathrm{dL}$ and the highest value was $342 \mathrm{mg} / \mathrm{dL}$ with an average of $216.53 \mathrm{mg} / \mathrm{dL}$ and SD of $44.65 \mathrm{mg} / \mathrm{dL}$.

Table 2: Data characteristic of the samples

\begin{tabular}{llll}
\hline Variables & Gender & $\mathrm{n}$ & Mean \\
\hline Age (years) & Male & 34 & $59.91 \pm 9.35$ \\
& Female & 84 & $55.76 \pm 9.24$ \\
Abdominal circumference $(\mathrm{cm})$ & Male & 34 & $92.35 \pm 12.13$ \\
& Female & 84 & $90.17 \pm 10.42$ \\
$\mathrm{BMI}\left(\mathrm{kg} / \mathrm{m}^{2}\right)$ & Male & 34 & $25.75 \pm 5.06$ \\
& Female & 84 & $26.34 \pm 5.65$ \\
\hline
\end{tabular}

The minimum HDL value was $24 \mathrm{mg} / \mathrm{dL}$, the maximum value was $77 \mathrm{mg} / \mathrm{dL}$, the mean value was $47.25 \mathrm{mg} / \mathrm{dL}$ and $\mathrm{SD}$ of $11.52 \mathrm{mg} / \mathrm{dL}$. The minimum LDL value was $50 \mathrm{mg} /$ $\mathrm{dL}$, the maximum value was $259 \mathrm{mg} / \mathrm{dL}$ with an average of $127.47 \mathrm{mg} / \mathrm{dL}$ and SD of $37.42 \mathrm{mg} / \mathrm{dL}$. The minimum TG value was $49 \mathrm{mg} / \mathrm{dL}$ and the maximum TG value was $1157 \mathrm{mg} / \mathrm{dL}$ with the mean value of $233.63 \mathrm{mg} / \mathrm{dL}$ and SD of $144.97 \mathrm{mg} / \mathrm{dL}$ (Tables 1-6).

Table 3: Biomarker metabolic concentration of the samples

\begin{tabular}{lllll}
\hline Variables & Gender & $\mathrm{n}$ & Mean & SD \\
\hline Blood sugar levels & Male & 34 & 245.15 & 119.98 \\
\multirow{2}{*}{ Cholesterol } & Female & 84 & 258.36 & 141.14 \\
& Male & 34 & 209.76 & 41.80 \\
HDL & Female & 84 & 219.27 & 45.71 \\
& Male & 34 & 43.15 & 9.41 \\
LDL & Female & 84 & 48.90 & 11.93 \\
& Male & 34 & 130.47 & 32.33 \\
TG & Female & 84 & 126.25 & 39.41 \\
& Male & 34 & 199.62 & 87.88 \\
HbA1C & Female & 84 & 247.39 & 160.90 \\
& Male & 34 & 9.0 & 2.70 \\
HDL: High-density lipoprotein, LDL: Low-density lipoprotein, TG: Triglyceride, HbA1c: Glycated hemoglobin.
\end{tabular}

In the test studies, there was a difference in the average lipid profile level (HDL and TG) in controlled and uncontrolled Type 2 DM and also a difference in 
the average $\mathrm{HbA} 1 \mathrm{C}$ value in controlled type $2 \mathrm{DM}$ and uncontrolled type 2 DM $(p<0.005)$.

Table 4: Family history of the samples

\begin{tabular}{lll}
\hline Family history & Frequency & Percentage \\
\hline No family history & 82 & 69.5 \\
Family history & 36 & 30.5 \\
Total & 118 & 100.0 \\
\hline
\end{tabular}

\section{Discussion}

There were more females $(71.2 \%)$ than males $(28.8 \%)$ with Type 2 DM in this study. The high proportion of female in this study may be due to the nature of patients who were getting admitted to the primary health-care center. It happened due to the reason that more females seek for medical attention compared to males, because most of them are housewives and they have more spare time.

Table 5: Data of samples based on controlled and uncontrolled

\begin{tabular}{lll}
\hline Variables & Frequency & Percentage \\
\hline Controlled Type 2 DM & 51 & 43.2 \\
Uncontrolled Type 2 DM & 67 & 56.8 \\
Total & 118 & 100.0 \\
\hline DM: Diabetes mellitus. & &
\end{tabular}

Various studies have clearly established that Type 2 DM's complications are mainly due to chronic hyperglycemia that is harmful for health through several mechanisms: Dyslipidemia, platelet activation, and altered endothelial metabolism [13]. Lipid profile and DM were the important predictors for metabolic disturbance including dyslipidemia, hypertension, and cardiovascular disease [14]. Lipids play a key role in the pathogenesis of DM. Dyslipidemia as a metabolic abnormality is frequently associated with DM.

Table 6: T-test of the results

\begin{tabular}{lc}
\hline t-test & $\mathrm{p}$ value \\
\hline HbA1c & $<0.005$ \\
Cholesterol & $>0.005$ \\
HDL & $<0.005$ \\
LDL & $>0.005$ \\
TG & $<0.005$ \\
CRI & $<0.005$ \\
TD systole & $>0.005$ \\
TD diastole & $>0.005$ \\
BMI & $>0.005$ \\
\hline HbA1c: Glycated hemoglobin, HDL: High-density lipoprotein, LDL: Low-density lipoprotein, TG: \\
Triglyceride, BMl: Body mass index.
\end{tabular}

Abnormalities in lipid metabolism have been reported in patients who suffer from DM with the risk of cardiovascular arteriosclerosis [15]. In this study, it was found that the average serum levels of total cholesterol and TGs were significantly higher than the normal value, which are known as risk factors for cardiovascular diseases among patients. Patients with type 2 DM were twice as likely to develop cardiovascular disease than those without DM regardless of age, smoking status, $\mathrm{BMI}$, and systolic blood pressure [16]. Furthermore, the mortality risk from vascular causes is more than doubled in patients with DM [17]. In this study, a difference in the average levels of HDL and TGs in the controlled and the uncontrolled type 2 DM was found. Improving glycemic control can substantially reduce the risk of cardiovascular events in diabetics [18]. Rina et al. stated that there was a correlation between $\mathrm{HbA} 1 \mathrm{c}$ levels and the total cholesterol serum in patients with uncontrolled Type 2 DM [19]. A study by Samdani et al. showed that there was a significantly positive correlation between $\mathrm{HbA1c}$ with lipid profile, especially LDL-C [20]. Other study conducted by Erciyas et al., also reported positive correlation of $\mathrm{HbA} 1 \mathrm{c}$ level with $\mathrm{TC}$ and $\mathrm{TG}$ in diabetic patients [21]. Goldberg reported that dyslipidemia in type 2 DM might be caused by dysfunctional insulin production which affects the liver apolipoprotein production and the apolipoprotein that regulates the enzymatic activity of lipoprotein lipase and cholesterol ester transport protein [22]. Another study by Ozder reported that there were a significantly higher average serum levels of TC, TG, and LDL and significantly lower average serum levels of $\mathrm{HDL}$ in patients with diabetes [23]. Diet control, exercise, and medicine have been the main treatments for patients with diabetes. A research by Widjaja et al. which incorporates traditional medicine like basil leaves extracts to decrease blood glucose showed that it could significantly lower blood glucose between the diabetic control group and the group treated [24].

In this study, the youngest participant was 35 years old and the oldest was 79 years old. There was a significant relation between the subjects' age with familial history. There was a significant relation between the occurrence of Type 2 DM, family history (from fraternal, maternal, or both), lifestyle factors, and genetics in the youngest participant [25], [26]. Several lifestyle factors are known to be important to the development of type 2 DM. These are physical inactivity, sedentary lifestyle, smoking status, and generous consumption of alcohol [27]. A study by Sari et al. reported that postprandial glucose levels were different in smoking compared to non-smoking diabetic patients. Smoking may contribute to the development of insulin resistance as there were higher postprandial glucose levels in smoking diabetic patients compared to the non-smoking diabetic patients [28]. Obesity has been found to contribute to approximately $55 \%$ of cases of type 2 DM [29]. Although individual predisposition to T2DM has a strong genetic basis, evidence from epidemiological studies suggests that many cases of T2DM can be prevented with lifestyle modifications [30].

Modification of lifestyle, including weight loss, increasing physical activity, and adopting a healthy diet, remains one of the first-line strategies for the management of T2DM to decrease lipid profile level, such as TGs and LDL and to increase HDL level [31]. A study by Rina et al reported that self-efficacy related to the management of diabetes in terms of selfmanagement has an impact on glycemic control and will certainly able to reduce complications and ultimately 
improve the life quality of patients [32]. Furthermore, self-efficacy behavior has a positive and significant effect on quality of life, metabolic level, and lipid control in type 2 DM patients [33], [34].

\section{Conclusion}

Uncontrolled type 2 DM was associated with increasing lipid profile that was known as a risk factor to cardiovascular complication. Better glycemic control of $\mathrm{HbA} 1 \mathrm{c}$ would also reflect on a better lipidemic state. $\mathrm{HbA1c}$ can be used as an indicator of glycemic control as well as a predictor of dyslipidemia in Type 2 DM.

\section{References}

1. Abou-Seif MA, Youssef AA. Evaluation of some biochemical changes in diabetic patients. Clin Chim Acta. 2004;346(2):161-170. https://doi.org/10.1016/j.cccn.2004.03.030 PMid: 15256317

2. Berry C, Tardif JC, Bourassa MG. Coronary heart disease in patients with diabetes: Part I: Recent advances in prevention and noninvasive management. J Am Coll Cardiol. 2007;49(6):631-42.

\section{PMid: 17291928}

3. Jain M, Jadeja JM, Mehta N. Correlation between $\mathrm{HbA} 1 \mathrm{c}$ values and lipid profile in Type 2 diabetes mellitus. Int J Basic Appl Physiol. 2013;2(1):47-50.

4. International Diabetes Federation. About Diabetes. Brussels, Belgium: International Diabetes Federation; 2020. Available from: https://www.idf.org/aboutdiabetes/what-is-diabetes.html. [Last accessed on $2020 \mathrm{Apr}$ 20]. https://doi.org/10.1016/j. diabres.2020.108029

5. Vinodmahato R, Gyawali P, Psd P, Regmi P, Singh K, Pandeya DR, et al. Association between glycaemic control and serum lipid profile in Type 2 diabetic patients: Glycated haemoglobin as a dual biomarker. Biomed Res. 2011;22(3):375-80.

6. Samatha P, Prabodh SV, Chowdary NV, Shekhar R. Glycated hemoglobin and serum lipid profile associations in Type 2 diabetes mellitus patients. J Pharm Biomed Sci. 2012;17(12):2230-7885.

7. Frank B, Stampfer J, Steven M. Elevated risk of cardiovascular disease prior to clinical diagnosis of Type 2 diabetes. Diabetes Care. 2002;25(7):1129-34.

PMid:12087009

8. Khatit M, Quazi S. Risk factors of Type 2 diabetes mellitus in rural Wardha: A community bared study. Int J Diabetes Dev Ctries. 2008;28(3):79-82. https://doi.org/10.4103/0973-3930.44077 PMid:19902039

9. American Diabetes Association. Standards of medical care in diabetes. Diabetes Care. 2007;30(Suppl 1):S4-41. https://doi. org/10.2337/dc07-s004 PMid:17192377

10. Joshua A, Becham B, Libby P. Diabetes and atherosclerosis: Epidemiology, pathophysiology, and management. JAMA. 2002;287(19):2570-81. https://doi.org/10.1001/ jama.287.19.2570

PMid:12020339

11. Sridhar RG. Diabetes in India: Snapshot of a panorama. Curr Sci. 2002;83:1-2

12. Analava $M$, Bhattacharya $D$, Roy S. Dietary influence on Type 2 diabetes (NIDDM). J Hum Ecol. 2007;21(2):139-47.

13. Taskinen MR. Diabetic dyslipidaemia: From basic research to clinical practice. Diabetologia. 2003;46(6):733-49. https://doi. org/10.1007/s00125-003-1111-y PMid: 12774165

14. Goldberg IJ. Clinical review 124: Diabetic dyslipidemia: Causes and consequences. J Clin Endocrinol Metab. 2001;8(3):965-71. PMid: 11238470

15. Krauss RM. Lipids and lipoproteins in patients with Type 2 diabetes. Diabetes Care. 2004;27(6):1496-504. https://doi. org/10.2337/diacare.27.6.1496

PMid:15161808

16. Seshasai SR, Kaptoge S, Thompson A, Di Angelantonio E, Gao P, Sarwar N, et al. Diabetes mellitus, fasting glucose, and risk of cause-specific death. N Engl J Med. 2011;364(9):829-41. https://doi.org/10.1056/nejmoa1008862 PMid:21366474

17. Selvin E, Wattanakit K, Steffes MW, Coresh J, Sharrett AR. $\mathrm{HbA1C}$ and peripheral arterial disease in diabetes: The atherosclerosis risk in communities study. Diabetes Care. 2006;29(4):877-82. https://doi.org/10.2337/diacare.29.04.06 . dc05-2018 PMid: 16567831

18. Sarwar N, Gao P, Seshasai SR, Gobin R, Kaptoge S, D Angelantonio $\mathrm{E}$, et al. Diabetes mellitus, fasting blood glucose concentration, and risk of vascular disease: A collaborative meta-analysis of 102 prospective studies. Lancet. 2010;375(9733):2215-22. https://doi.org/10.1016/ s0140-6736(10)60484-9

PMid:20609967

19. Amelia R, Damanik HA, Lindarto D, Mutiara E. The correlation between the level of $\mathrm{HbA} 1 \mathrm{c}$ with total serum cholesterol of uncontrolled Type 2 diabetes mellitus patients in Binjai, Sumatera Utara. Adv Sci Lett. 2017;23(4):3610-3. https://doi. org/10.1166/asl.2017.9193

20. Samdani T, Mitra P, Rahim MA. Relationship of glycated haemoglobin with lipid profile among patients with Type 2 diabetes mellitus. BIRDEM Med J. 2017;7(1):43-7. https://doi. org/10.3329/birdem.v7i1.31271

21. Erciyas F, Taneli F, Arslan B, Uslu Y. Glycemic control, oxidative stress and lipid profile in children with Type 1 diabetes mellitus. Arch Med Res. 2004;35:134-40. https://doi.org/10.1016/j. arcmed.2003.10.002 PMid: 15010193

22. Goldberg IJ. Lipoprotein lipase and lipolysis: Central roles in lipoprotein metabolism and atherogenesis. J Lipid Res. 1996;37(4):693-707. PMid:8732771

23. Ozder A. Lipid profile abnormalities seen in T2DM patients in primary healthcare in Turkey:Across-sectionalstudy. Lipids Health Dis. 2014;13:183. https://doi.org/10.1186/1476-511x-13-183

24. Widjaja SS, Rusdiana R, Savira M. Glucose lowering effect of basil leaves in diabetic rats. Open Access Maced J Med Sci. 2019;7(9):1415-7. https://doi.org/10.3889/oamjms.2019.293 PMid:31198445

25. Ripsin CM, Kang H, Urban RJ. Management of blood glucose in Type 2 diabetes mellitus. Am Fam Physician. 2009;79(1):29-36. PMid: 19145963

26. Fuchsberger C, Flannick J, Teslovich TM, Mahajan A 
Agarwala $\mathrm{V}$, Gaulton KJ, et al. The genetic architecture of Type 2 diabetes. Nature. 2016;536:41-7.

PMid:27398621

27. Hu FB, Manson JE, Stampfer MJ, Colditz G, Liu S, Solomon CG, et al. Diet, lifestyle, and the risk of Type 2 diabetes mellitus in women. N Engl J Med. 2001;345(11):790-7. https://doi. org/10.1056/nejmoa010492

PMid: 11556298

28. Schellenberg ES, Dryden DM, Vandermeer B, Ha C, Korownyk C. Lifestyle interventions for patients with and at risk for Type 2 diabetes: A systematic review and metaanalysis. Ann Intern Med. 2013;159(8):543-51. https://doi. org/10.7326/0003-4819-159-8-201310150-00007

PMid:24126648

29. Sari MI, Sari N, Darlan DM, Prasetya RJ. Cigarette smoking and hyperglycaemia in diabetic patients. Open Access Maced J Med Sci. 2018;6(4):634-7. https://doi.org/10.3889/oamjms.2018.140 PMid:29731929

30. Wadden TA, West DS, Delahanty L, Jakicic J, Rejeski J, Williamson $\mathrm{D}$, et al. The Look AHEAD study: A description of the lifestyle intervention and the evidence supporting it. Obesity (Silver Spring). 2006;14:737-52. https://doi.org/10.1038/oby.2006.84
PMid: 16855180

31. Centers for Disease Control and Prevention (CDC). Prevalence of overweight and obesity among adults with diagnosed diabetes. United States, 1988-1994 and 1999-2000. MMWR Morb Mortal Wkly Rep. 2004;53(45):1066-8. https://doi.org/10.15585/mmwr. $\mathrm{mm} 6545 \mathrm{a} 4$

PMid:15549021

32. Goldfine $A B$, Beckman JA. Life and death in Denmark: Lesson about diabetes and coronary heart disease. Circulation. 2008;117:1914-7. https://doi.org/10.1161/ circulationaha.108.767681

33. Amelia R. The model of self care behavior and the relationship with quality of life, metabolic control and lipid control of Type 2 diabetes mellitus patients in Binjai City, Indonesia. Open Access Maced J Med Sci. 2018;6(9):1762-7. https://doi.org/10.3889/ oamjms.2018.363

PMid:30338004

34. Amelia R, Ariga RA, Rusdiana, Sari MI, Savira M. Self-efficacy in Type 2 diabetes mellitus patients and the relationship with the quality of life in Medan City. J Phys Conf Ser. 2018;1116(5):052003. https://doi. org/10.1088/1742-6596/1116/5/052003 